\title{
Supervisors' Dark Triad and Abusive Supervision: Does Islamic Work Ethics Help?
}

\author{
Naeem Ahmed Tahir ${ }^{1 *}$, Khurram Khan ${ }^{2}$, Sajjad Hussain ${ }^{3}$ \\ 1,2 Faculty of Management Sciences, Riphah International University, Islamabad, Pakistan \\ ${ }^{3}$ Faculty of Management Sciences, Foundation University, Islamabad, Pakistan
}

\section{Keywords}

Supervisors' Dark Triad

Abusive Supervision

Islamic Work Ethic

Burnout

Counterproductive Work

Received: 09 July 2020

Accepted: 31 July 2020

\begin{abstract}
The Dark Triad in the Workplace Research is an underinvestigated avenue of research. This conceptual study proposes the supervisors' dark triad personality as an antecedent to their abusive supervision. The study suggests that the supervisor's abusive behavior would trigger burnout and counterproductive work behaviors among the employees that are caused by negative personality traits i.e. dark triad. The study further proposes that Islamic Work Ethics may play a critical role to cope up with these negative workplace behaviors due to its nature of a buffering agent. Finally, the study concludes with important implications of Islamic Work Ethics towards new avenues of research in Dark Triad personality and its hazardous effects in the workplace.
\end{abstract}

KAUJIE Classification: H54, M84

JEL Classification: M12, M1, L2

(C) 2020 JIBM. All rights reserved.

\section{INTRODUCTION}

"Employees don't quit their job, they quit their boss" (Goler et al., 2016).

A major reason for employees to quit their jobs is their bosses, and the biggest problem with their supervisor is the hostile and abusive attitude of the bosses (Tepper et al., 2017). Abusive supervision impacts $13.6 \%$ of U.S. workers. In general, The United States' economy (due to health-related costs, huge losses of productivity and high rates of absenteeism) suffers up to $\$ 23.8$ billion, annually (Tepper et al., 2006). The concept of the dark triad was initiated by Paulhus and Williams (2002). It consisted of Machiavellianism, Narcissism and Psychopathy. Dark triad appears to be a major antecedent of abusive supervision (Spain et al., 2014). Moreover, abusive supervision is a major challenge in today's world (Douglas et al., 2020). It is contextually very relevant to eastern societies (Kernan et al., 2011). Pakistan is a high power distance society (Khilji, 2002). High power distance creates abusive supervision (Martinko et al., 2013). When the power distance is high, there is a huge gap between the less powerful and more powerful i.e between subordinate and boss, which also contributes

\footnotetext{
${ }^{*}$ Corresponding author: Naeem Ahmed Tahir

†Email: alnaeems@gmail.com
} 
in making a supervisor Abusive. Another factor is unemployment in the country (Qayyum $\&$ Siddiqui, 2007). Due to high unemployment, abusive supervision becomes considerably evident hence, it becomes a much-needed area of research especially in this region of the world.

If practitioners can reduce or control abusiveness, they can expect better productivity (Tepper et al., 2017), low turnover, and higher job satisfaction (Tepper, 2000). Organizational justice perspective (including interactional justice) also supports these job outcomes, as when people believe they have been dealt properly they tend to exhibit positive job outcomes (Khan et al., 2015). For this, we looked for the boundary condition of Islamic work ethics; possibly, this can provide us with required assistance in the above-mentioned relationship and can moderate between abusive supervision and job outcomes.

There is a growing body of knowledge that focuses on the causes and consequences of abusive supervision. Three meta-analytic studies have been conducted so far to examine the antecedents and consequences of abusive supervision (see, Mackey et al., 2017; Zhang \& Bednall, 2016; Zhang \& Liao, 2015). However, despite these meta-analyses, researchers still need to explore what supervisory characteristics trigger abusive supervision, as the antecedent conditions to abusive supervision are not completely explored. For example, despite its theoretical relevance, prior research has largely ignored the possible effects of negative personality disorders like supervisors' dark triad (i.e., narcissism, Machiavellianism, and Psychopathy) on abusive supervision.

Historically, the traits i.e. Narcissism and Psychopathy were considered personality disorders and were dealt with in the clinical side of the literature (Furnham et al., 2013). Narcissism is often perceived as getting pleasure from one's self-praise especially through one's self-defined image. Psychopathy has been considered as a personality disorder and was dealt in the clinical side of the literature (Furnham et.al, 2013). The third trait of dark triad Machiavellianism was named after the famous author of 15th-century Machevillee (known for his book The Prince, Suchowlansky, 2017).

Machiavellianism refers to making use of unscrupulous and deceiving behaviors with intentions to underestimate and devalue other people (Jonason et al., 2012). Researchers see it as an interesting phenomenon of categorizing these personality disorders to the mainstream personality literature (Furnham et al., 2013). Dark Triad (DT) is defined by Paulhus and Williams (2002) as people having these characters had a common tendency to be heartless, spiteful, and selfish in their interpersonal collaborations.

Similarly, prior research has explored several moderators in the relationship between abusive supervision and job outcomes. However, the possible boundary conditions for the effects of supervisor-related antecedents on abusive supervision are unknown. In other words, researchers are yet to explore whether the antecedent conditions (e.g., dark triad) always trigger abusive supervision. This study suggests that the antecedents would not always trigger abusive supervision rather their effects may be conditional on the level of support an employee receives from his/her organization. Furthermore, past research has demonstrated that the effects of abusive supervision on job outcomes are moderated by several personal and cultural characteristics (Zhang \& Liao, 2015). 
Prior research has underexplored the possible moderating role of Islamic work ethics (IWE) that is an orientation based on the role of Islamic ethical values in the workplace. This influences the involvement and participation of believers in the workplace. It implies that work is a virtue in light of a person's needs, and is a necessity for establishing equilibrium in one's individual and social life (Ali, 1992). Islamic workplace ethics see work as a source of Halal Income and people who believe in Islamic work values are more tolerant to negative behaviors and more inclined towards pro-social behaviors (Hussain et al., 2018). And have patience with what they say, and leave them with noble (dignity) (Qur'ān 73:10). Allah Almighty emphasizes in Qur'ān about patience and tolerance on indecent behaviors from colleagues and bosses (Tufail et al., 2018). Hence, as abusive supervision is categorized as a workplace stressor (Zhang \& Bednall, 2016), IWE will buffer against the harmful effects of abusive supervision on job outcomes.

Based on these gaps and justifications, the current study has the potential to provide significant contributions to the body of literature in many ways. First, the study will theoretically examine the possible effects of the dark triad as a negative personality-oriented antecedent to abusive supervision. Second, the study will be the first study, as per my knowledge, to propose the moderating role of Islamic work ethics in this context. Third, the study contributes to the theory by proposing abusive supervision as a possible mediator between negative leadership and its workplace behavioral outcomes. Fourth, it extends the applications of Islamic work ethics as a panacea to negative role plays within the socio-cultural settings and its detrimental effects. In this way, this theoretical investigation, with particular reference to its relevance to the local socio-cultural context would be an added value. Finally, this work, based on the theoretical foundations laid by earlier researchers on the IWE helps in making the indigenous solutions to local problems. Therefore, it is argued that this study is a significant contribution to Muslim Cultures and it may help to understand our socio-cultural contexts and to improve the functioning of institutions.

\section{LITERATURE REVIEW}

\section{Abusive Supervision}

According to the definition of abusive supervision by Tepper (2000); it is the "subordinates' perceptions of the extent to which supervisors engage in the sustained display of hostile verbal and nonverbal behaviors, excluding physical contact". This definition carries several significant elements. Firstly, employees make a subjective assessment of abusive supervision, basing it on their observations and experiences with their managers' conduct. Such type of assessment could be painted by the characteristics, demography, and personality of the subordinate/observer, and also of the context of the whole assessment, such as perceptions of the coworker and actual work environment. Secondly, sustained exhibitions of non-physical aggression are referred to by abusive supervision. Abusive supervision also has ongoing contact with hierarchical mistreatment. If the supervisor mistreats his/her subordinate for any reason, and that behavior becomes a regular feature of his/her attitude, then only in such a condition it can be termed as abusive supervision.

Another main point about the conceptualization of Tepper (2000) is that abusive supervi- 
sion belongs to the sphere of conscious deeds. This means that abusive leaders display such conduct for a reason. They hold some reason and objective in mind and to achieve that they show such behavior to their subordinates. Abusive supervisors can hurt subordinates and mistreat them to accomplish their personal goals. For instance, a manager could maltreat juniors to produce higher performances or to give a message about being intolerant towards any mistakes, and these types of behavior indications are the essential parts of abusive supervision. Abusive supervision is different from Work Aggression, as the intent of the abusive supervisor is to harm his/her subordinate with or without any objective or purpose. Whereas, work aggression involves deliberate attempts to cause injury.

\section{Narcissism and Abusive Supervision}

Narcissism is a cognitive-affective obsession with one's self (Giacomin \& Jordan, 2016; Westen, 1990). Narcissism is getting pleasure from self-praise especially through one's self-defined image. Campbell et al. (2002) noted that the term originally came from Greek legends. According to them, Narcissists are people who start loving their image upon seeing it in the pool of water in their adolescence. Narcissism is deemed as a cultural or social problem and it is utilized in many inventories of personality relating to self-report as a factorin-trait theory. Narcissism is counted among the three main dark triadic traits of personality, alongside Machiavellianism and Psychopathy being the other two.

The Narcissistic Personality Inventory (NPI) is a recurrently used measure of narcissism and it involves elements of supremacy and leadership, giving rise to feelings to an individual as if he is the best in the world; lavish boosting like the individual is going to get all the attention in the world; and a feeling of prerogative in terms of the person having the absolute right to get the respect from others (Raskin \& Hall, 1979).

In one study applied to the workplace, Penney and Spector (2002) found that narcissism played a moderating role between the association of experiencing job restrictions and involving in Counterproductive Work Behaviors (CBWs). The authors argue that job constraints (e.g., poor equipment, constant interruptions) represent a threat to one's ego because they prevent an employee from demonstrating effective job performance. As per the findings of the researchers, individuals having a high level of narcissism responded extra adversely toward the job limitations through their engagement in additional CWBs like deliberately performing improperly and being insolent towards colleagues. Wang and Jiang (2014) in their study investigated the links of narcissism with other factors such as juniors' views about abusive management and nonconformity towards the manager. The results of their study highlighted the matter as narcissism and abusive management were found significantly and negatively linked to each other. Correlation analysis of their study show narcissism was negatively tied to abusive supervision $(r=-.11)$. The linear regression's outcomes also specified a tiny but significantly adverse relationship of narcissism with abusive supervision $\left(R^{2}=.02\right)$. At times, it is secured to have constructive views about the self as this may result in positive fallouts (Diener, 1984); however, the outcomes might be adverse when such constructive self-views are produced by narcissism. This research work pointed out that the underlings of narcissistic are highly expected to act aggressively in response to abusive administration 
compared to the responses coming from their non-narcissistic counterparts. Baumeister et al. (2000) explained that this kind of situation takes place when subordinates of narcissism with high-intensity pose pressures to an individual's ego without any problems and such a state spurs a violent reaction to abusive supervision. It is tough for the persons with narcissism to pardon maltreatment or even undesirable feedback coming from other people (Exline et al., 2004); hence, such narcissistic individuals are likely to be inclined to take revenge from abusive managers in hostile ways (Mitchell \& Ambrose, 2007). Given all research findings related to narcissism, we expect that narcissism negatively influences abusive supervision. Thus, we conclude the proposition for the relationship between these two variables as:

Proposition 1: Supervisor's narcissism is positively related to the employee's perception of abusive supervision.

\section{Psychopathy and Abusive Supervision}

The main symptoms of Psychopathy include lack of concern for other people in society, impulsiveness, and lack of guilt when they harm other people. They are good impression maker managers with a superficial and charismatic personality. They are emotionally shallow, their lifestyles are parasitic and they are involved in criminal activities (Hare \& Neumann, 2009). Recent studies show that there is a linkage between Psychopathy and such behaviors by way of academic cheating (Nathanson et al., 2006); using unfair means (Jonason et al., 2009). Additionally, adding in more literature from works related to this specific topic may also profit supervisors and corporations by dropping the chances of negative results that might be accompanied by the Psychopathy of workers.

Proposition 2: Supervisor's Psychopathy is positively related to the employee's perception of abusive supervision.

\section{Machiavellianism and Abusive Supervision}

Machiavellianism means making use of unscrupulous and deceiving behaviors with intentions to underestimate and devalue other people (Jonason et al., 2012). It has been found out by several scholars that people with a high level of Machiavellianism as well as having the other two dark behaviors-narcissism and Psychopathy - have a tendency to utilize destructive conduct and tactics of influencing others including their superiors. Workers with high scores of Machiavellianism, Psychopathy, and narcissism are likely to display abnormal manners to express their belligerence or to have vengeance (Jonason et al., 2012).

It is generally thought that Machiavellians are cynical with pessimistic ideas and insensitivity, they are making efforts to achieve their aggressive monetary objectives, and they tend to use manipulative strategies (Christie \& Geis, 1970). Individuals with at least one of these traits are often viewed as unproductive leaders in one way or the other (Babiak et al., 2010).

Machiavellians and abusive supervision are investigated by very few researches. Like it is found by Kiazad et al., (2010), the Machiavellianism of a manager is positively related to reporting employees' perceptions of abusive management. There is a positive connection between leader Psychopathy with self-serving conduct and abusive management. These associations are observed weak in organizations that have a stronger ethical culture (Laurijssen $e t$ 
al., 2016).

Proposition 3: Supervisor's Machiavellianism is positively related to the employee's perception of abusive supervision.

\section{Abusive Supervision and Counterproductive Work Behavior}

Due to abusive supervision, employees feel defenceless, exasperate, and estrange (Ashforth, 1994), therefore, some employees may retort by retaliating against their organization by displaying counterproductive work behavior (CWB) (Bruk-Lee \& Spector, 2006; Lian et al., 2012). In-fact, it has come into notice that only feeling of abusiveness could prove to be enough for generating CWB (Marcus \& Schuler, 2004). Gouldner (1960) retaliatory responses of this kind can be understood through the social exchange theory that suggests that subordinates are likely to treat their superiors exactly the way they are normally handled by them. Furthermore, employees may consider their higher-ups as spokespersons and face of their organization and they might count their companies to be liable for the maltreatment to them from their managers considering that the organization failed in safeguarding them from abusive treatment (Bruk-Lee \& Spector, 2006; Schoss et al., 2013). Therefore, while reciprocity could point out the direct cause of abusive style of management, it could likely be linked with the organization directly as indicated in the displaced aggression theory, primarily in the presence of power variations between subordinates and supervisors (Mitchell \& Ambrose, 2007).

Proposition 4: Abusive supervision is positively related to employee's CWB.

\section{Abusive Supervision and Burnout}

The idea of burnout was first introduced by Herbert Freuden Berger who was a psychoanalyst in a New York-based clinic (Shepherd et al., 2011). Burnout is a condition where employees get too stressed and feel like he/she has a low level of energy and less confidence. Due to burnout, employees' interest in their work and his/her performance is reduced. The main effects of burnout on the organization are, the individual's performance is reduced, similarly, job satisfaction and organizational commitment levels of employees are lowered, and it may result in turnover intentions. Maslach and Jackson (1979) explained that burnout is the condition of emotional exhaustion. Job burnout mainly comprises emotional suffering, decreased sense of individual acceptance depersonalization (Lambert, 2010).

The factors which are responsible for causing burnout have been studied by many types of research. Some researches like (Ghorpade et al., 2007) studied the causes of burnout as why this emotional exhaustion is caused, while other researches like (Beehr \& Newman, 1998; Savicki \& Cooley, 1983) studied why some employees prosper and others feel stressed. This study inferred that the main reasons for the occurrences of burnout lie in the organizational environment. Job burnout can be caused due to multiple reasons. These reasons can be individual, environmental, and organizational factors. Organizational reasons which give rise to burnout include supervision style, strict rules at the workplace, low chances of promotion, and low level of job security (World Health Organization, 1998). Management style like abusive supervision can lead to job burnout and employee can feel too low and stressed. If 
subordinates experience abusive supervision, they would be too stressed and their interest level will decrease, which will affect their performance as well as organizational performance. Due to abusive supervision employees feel defenceless, exasperate, and estrange (Ashforth, 1994), therefore, some employees may retort by retaliating against their company by displaying a counterproductive work attitude (Bruk-Lee \& Spector, 2006; Lian et al., 2012). According to Kernan et al. (2011), subordinates usually show respect to their supervisors even if they are employing abusive management style. Tepper (2000) stated that because of the abusive style of management, adverse emotions are produced in the subordinates which cause low motivation and interest level and ultimately causes burnout and higher turnover intentions. Cordes et al. (1997) classified the reasons for burnout in four sub-classes i.e., organizational characteristics, job characteristics, role characteristics, and personal characteristics. According to Jackson and Schuler (1983) there are some causes, and consequences of employee burnout. The causes may be a lack of reward, promotion, motivation, management support, and the main negative outcomes can be a low performance on job, family and health issues, and mental stress. According to Lee and Akthar, (2007), the total solution to solve this issue is to state job description specifically for each position and post. Hence, we propose that:

Proposition 5: Abusive supervision is positively related to employee's CWB.

\section{Abusive supervision as a Mediator between Dark Triad and Job Outcomes}

Many research studies have concluded that it is not merely a point about the strength of a trait that is exhibited by a negative manager's behavior (Krasikova et al., 2013; Padilla et al., 2007); it in-fact, is the blend of dispositional propensities and other circumstantial factors which anticipate the frequency of the behavior of the negative leader. This is why there are few elements, which could enable managers having dark traits to be involved in abusing, while some other ones can subdue these types of actions. This study comments that the extent to which managers with Machiavellianism and/or Psychopathy are going to be contemplated within their conduct towards their employees is contingent upon the level of authority such leaders possess.

Plain sensitivity towards abuse compared to essentially reported instances, could be adequate for causing CWB (Marcus \& Schuler, 2004). Retaliatory responses of this kind can be understood via the social exchange theory, which postulates that employees are likely to behave with their superiors the way they are usually handled by them (Gouldner, 1960). According to Bruk-Lee and Spector, 2006; employees may consider their higher-ups as spokespersons and face of their organization and they might count their companies to be liable for the maltreatment to them from their managers considering that the organization failed in safeguarding them from abusive treatment. Hence, while reciprocity could point out the direct cause of abusive style of management, it could likely be associated with the organization as indicated in the displaced aggression theory, primarily in the presence of power variations between subordinates and supervisors (Mitchell \& Ambrose, 2007). As stated by the social exchange theory, the rule of reciprocity is highly valuable in exchange. The employees, who are respected in an organization, will return it to others and will display 
much better behavior, showing a higher level of organizational commitment. In that case, such employees will have greater job satisfaction and lesser turnover intentions. Conversely, the research study conducted by Cropanzano and Mitchell (2005) indicates that an employee is highly likely to display hostile behavior if he is working under an abusive administration. With a substantial gap between competence and position of the staff and their supervisors, it is unlikely to achieve tit for tat situation. Tepper (2001) found out in their study that employees' retaliation will not assist in controlling abusive management styles, it rather will likely boost up the abusive manager's anger, causing an increase in the intensity of abusive style of supervision. Based on this theory, workers opt to adopt soft, gentle, and cautious methods to get revenge from the abusive leadership and this establishes counterproductive behaviors in the employees. In organizations, when workers perceive that hostility to supervisors cannot end up abusive supervision, they adopt to give harm to the organization i.e., they take harmful actions against the organization. In a study of the predecessors of CWB, Berry et al. (2007) determined that five major aspects of human personality - agreeableness, extroversion, neuroticism, conscientiousness, and openness to experience are closely connected with CWB which targets the organization. The literature discussed above clarifies that abusive supervision has a mediating role to play between dark triads and CWB. When abusive supervision will be high, employees will be mentally disturbed, their personalities will be distorted and they can turn on to dark triad traits, due to which they involve in CWBs.

Proposition 6: Abusive supervision will mediate between dark triad and Job outcomes.

\section{Islamic Work Ethics acts as a Moderator in the Relationship of Abusive Supervision with Job Outcomes}

We finally propose that IWE would act as a buffering agent against the harmful effects of abusive supervision. Employees with contrasting contexts may respond differently to abusive supervision (Khan et al., 2015). But one impact is common for all contexts that it will harm the organizational outcomes such as productivity, loyalty, and performance. It will also harm the concerned individual/s in their personal outcomes; such as, it will increase stress and burnout anxiety in people (Priesemuth et al., 2014). It is concluded that IWE will moderate and work as a buffer (Ahmad, 2011) between abusive supervision and work, and personal outcomes i.e., it will decrease deviant workplace behaviors. Moreover, one of the major consequences of abusive supervision is stress and burn out (Khan et al., 2015); IWE will also work as a buffer here, as people with high IWE's have peace of mind (Khan et al., 2015), which helps them co-op better against stress and burn out. The reason people with high IWE's co-op stress better is their contentment, belief in the life hereafter (Javed et al., ) and a very strong belief on qadar/destiny (Javed et al., 2019).

In normal settings, if the boss is abusive, employees respond with negativity in some other form i.e., they may engage in behaviors harmful for the organization (CWB) or damaging for themselves, such as stress and burnout (Javed et al., 2019). But IWE gives them a sense of purpose and promise of ajr and virtue of sabr (Javed et al., 2019). In such cases, those employees who have higher work ethics will be less vulnerable to the deleterious effects of abusive supervision. IWE would help these employees in coping with the stress related to 
supervisory abuse. These individuals, because of high work ethics, would not compromise on their work, even if they face abuse from their supervisors. Consequently, we suggest the following:

Proposition 7: IWE will moderate the relationship between abusive supervision and job outcomes such that the relationships will be weak (stronger) for high (low) levels of IWE.

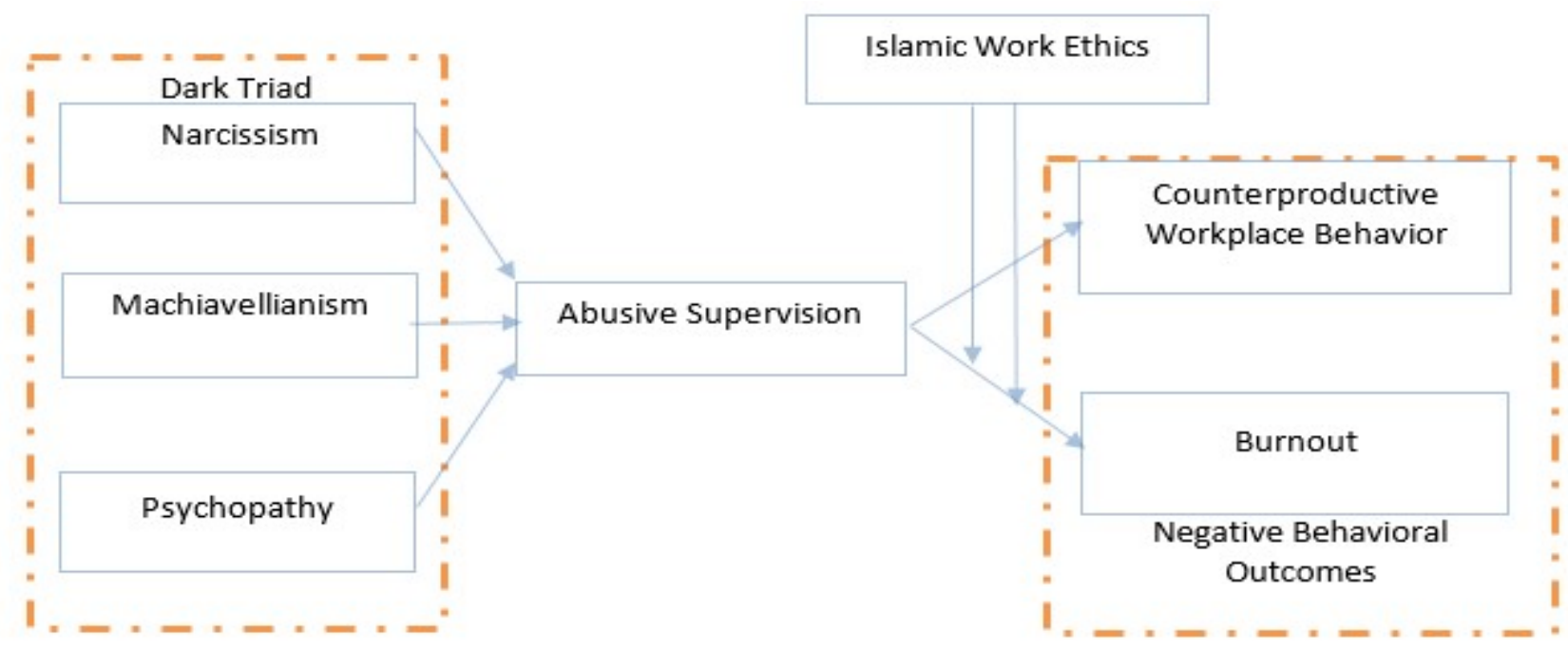

FIGURE 1. Research model

\section{METHODOLOGY}

Authors reviewed 48 source documents on Dark triad, abusive supervision, counterwork behavior, and burnout having prospective links with Islamic work ethics. These are peerreviewed journals recognized by the Higher Education Commission of Pakistan (HEC). The procedure of review is as suggested by Denyer and Tranfield (2009), and Macpherson and Jones (2010) follows the following steps:-

1. Setting Research question

a. Contribution of Dark Triad in Abusive Supervision

b. Role of Islamic Work ethics for negative organizational operatives

2. Defining theoretical areas

a. Negative leadership traits and their consequences

b. Religion-based ethics

3. Searching Papers

a. Inclusion criteria (Peer reviewed, HEC Recognized Journals)

b. Search engines and databases (HEC Databases, PERN, Google Scholar)

c. Keywords for searching (Dark triad, abusive supervision, counterwork behavior, burnout, Islamic Work Ethics)

d. Period: 1994 to 2020.

e. Source validation (Matching HEC criteria) 


\section{Discussion}

With social dissemination happening across the world, numerous fields of study are profoundly interlaced, consequently expanding our comprehension of all-encompassing different backgrounds. This examination paper is pointed towards understanding what Islamic standards state with respect to authoritative conduct and brain science. Various investigations propose that religion plays a major role in shaping individuals' cognitions, attitudes and behaviors. This, in turn, shapes up how they live, cooperate, and carry on inside the general public (Javed, 2017). The examination draws plentiful proof from Qur'ān and hadìth, and other striking artistic commitments to point that Islam not just recognizes the likely effect of the above factors on any association, yet additionally gives a whole blueprint to deal with the attitudinal and conduct aspects of authoritative life in the best way. This paper gives an understanding of the relationship among variables that can erode social fabrics. Moreover, it proposes that IWE can play a role of panacea to reduce the intensity of negative consequences of the dark triad. Since Islam is the second-largest religion on earth, the implications of the study are very vital.

Islam lectures generosity, mercy, and graciousness in both discourse and deeds. IWE advocates that believers must be moderate in their walking pace, and they should speak with a softer tone. The biggest foul-tasting of sounds is the voice of donkey (Qur'ān, 31:19). There is an assortment of occurrences where Prophet (PBUH) demanded embracing politeness while talking. He (PBUH) stated, "Don't be minimal even the most diminutive thoughtful gesture, yet it were no very gathering your sibling with a grinning and sprightly face" (Tirmidhi- Vol 3, Book 23, Hadīth 1833). Subordinates who saw their bosses were more abusive were bound to stop their employments. The individuals, who experienced abusive supervision, were disengaged, less satisfied, more inclined to leave the organization. Abusive supervision was also linked to a lack of commitment, lack of discipline, work-family conflict, and mental illness. Qur'ān pronounces not to eat up each other's property unfairly, nor toss it under the watchful eye of the adjudicators in order to eat up a portion of other's property shamefully and intentionally (2:188).

Qur'ān demonstrates an alluring signal of truth adherents as that when the stupid location them (with terrible words), they (devotees) answer back with salamah (serene expressions of tenderness) (25:63).

Qur'ān tells the believers that leniency from Allah that Prophet (PBUH) essentially were delicate with mankind. On the off chance that Prophet (PBUH) had been harsh or hard of heart; individuals may have spread from around the Prophet (PBUH). So, Allah asked the sacred Prophet (PBUH) to exculpate and approach pardoning for devotees (3:159).

The Prophet (PBUH) announced a tough individual as not an individual that tosses his/her enemies to the ground; however, a vigorous individual is that the one that contains himself when he's irate (Muwatta: 47:12). In another hadith, Prophet (PBUH)said that nobody has gulped back much else astounding inside seeing God, who is Great and Glorious, than outrage, looking to satisfy God (Ibn-e-Majah, Vol 5, Book 37, No. 4189). The Prophet (PBUH) said that our life, properties and respect are as holy to one another as the holy day, month and city on haj (Bukhari, Muslim and Abi Daud). This obviously demonstrates the 
accentuation on the security of the hierarchical and relational properties and to keep away from deeds that are counter work and inefficient.

Earlier studies indicate that construct of IWE is an under-explored and less examined construct to address negative job directed behaviors. Working for an environment with high IWE is the path that can improve work environment. This shapes and impacts the inclusion and interest of adherents inside the working environment. It suggests that work could likewise be righteousness considering an individual's needs, and ought to be a need for setting up balance in one's individual and public activity (Ali, 1992). Islamic working environment morals consider work to be a wellspring of Halal income and individuals who trust Islamic work esteems are more distant to negative practices and more slanted towards pro-social practices (Hussain, Shahzad, Khan, and Ahmad, 2018). Like Allah accentuates in Qur'ān stanzas about the persistence, resilience, and tolerant to foul practices from partners and chiefs (Tufail et al., 2019). Since, abusive supervision is a work environment stressor (Zhang \& Bednall, 2016), IWE can guard against the destructive impacts of abusive supervision on job outcomes.

\section{Conclusion}

This conceptual study reviewed the supervisors' dark triad personality as an antecedent to their abusive supervision. The study suggested that the supervisor's dark triad would trigger burnout and CWBs among the employees directly or indirectly through abusive supervision. The study further discusses the critical role of IWE as a buffering agent that helps employees to cope with the harmful effects of abusive supervision on job outcomes. The review suggested that the dark triad of a supervisor can be a major source of his or her abusive supervision, which in turn would trigger burnout and counterproductive behaviors among the subordinates. It is recommended that an employee's IWE would help him or her to cope up with the detrimental effects of abusive supervision. Future research may empirically test these relationships to provide empirical evidence on the proposed relationships. This will be a good prospect for future research on abusive supervision and its detrimental effects within the workplace environment.

\section{REFERENCES}

Ali, A. J. (1992). The Islamic work ethic in Arabia. The Journal of Psychology, 126(5), 507-519. doi: https://doi.org/10.1177/0022022198292007

Ahmad, M. S. (2011). Work ethics: An Islamic prospective. Journal of Human Sciences, $8(1), 850-859$.

Ashforth, B. (1994). Petty tyranny in organizations. Human Relations, 47(7), 755-778. doi: https://doi.org/10.1177/001872679404700701

Babiak, P., Neumann, C. S., \& Hare, R. D. (2010). Corporate psychopathy: Talking the walk. Behavioral Sciences $\mathcal{E}$ the Law, 28(2), 174-193. doi: https://doi.org/10.1002/bsl.925

Baumeister, R. F., Bushman, B. J., \& Campbell, W. K. (2000). Self-esteem, narcissism, and aggression: Does violence result from low self-esteem or from threatened egotism?. Current Directions in Psychological Science, 9(1), 26-29. doi: https://doi.org/10.1111/1467-8721.00053 
Beehr, T. A., \& Newman, J. E. (1998). Research on occupational stress: An unfinished enterprise. Personnel Psychology, 51(4), 835-844.

doi: https://doi.org/10.1111/j.1744-6570.1998.tb00741.x

Berry, C. M., Ones, D. S., \& Sackett, P. R. (2007). Interpersonal deviance, organizational deviance, and their common correlates: A review and meta-analysis. Journal of Applied Psychology, 92, 410-424. doi: https://doi.org/10.1037/0021-9010.92.2.410

Bruk-Lee, V., \& Spector, P. E. (2006). The social stressors-counterproductive work behaviors link: Are conflicts with supervisors and coworkers the same?. Journal of Occupational Health Psychology, 11(2), 145-156. doi: https://doi.org/10.1037/1076-8998.11.2.145

Campbell, W. K., Foster, C. A., \& Finkel, E. J. (2002). Does self-love lead to love for others? A story of narcissistic game playing. Journal of Personality and Social Psychology, 83(2), 340-354. doi: https://doi.org/10.1037/0022-3514.83.2.340

Christie, R., \& Geis, F. (Eds.) (1970). Studies in machiavellianism. Academic.

Cordes, C. L., Dougherty, T. W., \& Blum, M. (1997). Patterns of burnout among managers and professionals: A comparison of models. Journal of Organizational Behavior: The International Journal of Industrial, Occupational and Organizational Psychology and Behavior, 18(6), 685-701.

doi: https://doi.org/10.1002/(SICI)1099-1379(199711)18:6<685::AID-JOB817>3.0.CO;2Udo

Cropanzano, R., \& Mitchell, M. S. (2005). Social exchange theory: An interdisciplinary review. Journal of Management, 31(6), 874-900.

doi: https://doi.org/10.1177/0149206305279602

Denyer, D., \& Tranfield, D. (2009). Producing a systematic review. In D. A. Buchanan \& A. Bryman (Eds.), The sage handbook of organizational research methods (p. 671-689). Sage Publications Ltd.

Domingo, M. A. A., Du, C., Yoon, S., \& Yu, L. (2020). The third-decade of abusive supervision research: The role of time and emotion. In Academy of Management Proceedings, New York, NY. doi: https://doi.org/10.5465/ambpp.2016.10226symposium

Exline, J. J., Baumeister, R. F., Bushman, B. J., Campbell, W. K., \& Finkel, E. J. (2004). Too proud to let go: Narcissistic entitlement as a barrier to forgiveness. Journal of Personality and Social Psychology, 87(6), 894-912. doi: https://doi.org/10.1037/0022-3514.87.6.894

Furnham, A., Richards, S. C., \& Paulhus, D. L. (2013). The Dark Triad of personality: A 10 year review. Social and Personality Psychology Compass, 7(3), 199-216. doi: https://doi.org/10.1111/spc3.12018

Ghorpade, J., Lackritz, J., \& Singh, G. (2007). Burnout and personality: Evidence from academia. Journal of Career Assessment, 15(2), 240-256.

doi: https://doi.org/10.1177/1069072706298156

Giacomin, M., \& Jordan, C. H. (2016). Self-focused and feeling fine: Assessing state narcissism and its relation to well-being. Journal of Research in Personality, 63, 12-21. doi: https://doi.org/10.1016/j.jrp.2016.04.009 
Goler, L., Gale, J., \& Grant, A. (2016). Let's not kill performance evaluations yet. Harvard Business Review, 94(11), 90-94.

Gouldner, A. W. (1960). The norm of reciprocity: A preliminary statement. American Sociological Review, 25(2), 161-178. doi: https://doi.org/10.1080/15534510802131004

Hare, R. D., \& Neumann, C. S. (2009). Psychopathy: Assessment and forensic implications. The Canadian Journal of Psychiatry, 54(12), 791-802. doi: https://doi.org/10.1177/070674370905401202

Hussain, S., Shahzad, K., Khan, K., \& Ahmad, I. (2018). Moderating role of Islamic work ethics and mediating role of organizational identification on leader-member exchange and citizenship behavior relationship: A test of moderated mediation model. Journal of Islamic Business and Management, 8(1), 139-155. doi: https://doi.org/10.26501/jibm/2018.0801-009

Jackson, S. E., \& Schuler, R. S. (1983). Preventing employee burnout. Personnel, 60(2), 58-68.

Javed, S. (2017). Workplace behavioral dynamics in Islam-A holistic outlook. Journal of Islamic Business and Management, 7(2), 283-298. doi: https://doi.org/10.26501/jibm/2017.0702-009

Javed, B., Fatima, T., Yasin, R. M., Jahanzeb, S., \& Rawwas, M. Y. (2019). Impact of abusive supervision on deviant work behavior: The role of Islamic work ethic. Business Ethics: A European Review, 28(2), 221-233.

doi: https://doi.org/10.1111/beer.12212

Jonason, P. K., Slomski, S., \& Partyka, J. (2012). The dark triad at work: How toxic employees get their way. Personality and Individual Differences, 52(3), 449-453. doi: https://doi.org/10.1016/j.paid.2011.11.008

Jonason, P. K., Li, N. P., Webster, G. D., \& Schmitt, D. P. (2009). The dark triad: Facilitating a short-term mating strategy in men. European Journal of Personality: Published for the European Association of Personality Psychology, 23(1), 5-18. doi: https://doi.org/10.1002/per.698

Kernan, M. C., Watson, S., Fang Chen, F., \& Gyu Kim, T. (2011). How cultural values affect the impact of abusive supervision on worker attitudes. Cross Cultural Management: An International Journal, 18(4), 464-484.

doi: https://doi.org/10.1108/13527601111179528

Khan, K., Abbas, M., Gul, A., \& Raja, U. (2015). Organizational justice and job outcomes: Moderating role of Islamic work ethic. Journal of Business Ethics, 126(2), 235-246. doi: https://doi.org/10.1007/s10551-013-1937-2

Khilji, E. (2002). Modes of convergence and divergence: An integrative view of multinational practices in Pakistan. International Journal of Human Resource Management, 13(2), 232-253.

doi: https://doi.org/10.1080/09585190110102350

Kiazad, K., Restubog, S. L. D., Zagenczyk, T. J., Kiewitz, C., \& Tang, R. L. (2010). In pursuit of power: The role of authoritarian leadership in the relationship between supervisors' machiavellianism and subordinates' perceptions of abusive supervisory 
behavior. Journal of Research in Personality, 44(4), 512-519.

doi: https://doi.org/10.1016/j.jrp.2010.06.004

Krasikova, D. V., Green, S. G., \& LeBreton, J. M. (2013). Destructive leadership: A theoretical review, integration, and future research agenda. Journal of Management, 39(5), 1308-1338. doi: https://doi.org/10.1177/0149206312471388

Lambert, E. G. (2010). The relationship of organizational citizenship behavior with job satisfaction, turnover intent, life satisfaction, and burnout among correctional staff. Criminal Justice Studies, 23(4), 361-380.

doi: https://doi.org/10.1080/1478601X.2010.516533

Laurijssen, L. M., Wisse, B., \& Sanders, S. (2016). Harnessing against psychopathic leaders: Corporate psychopathy, destructive leadership, and the moderating role of ethical culture. Unpublished Manuscript.

Lee, J. S., \& Akhtar, S. (2007). Job burnout among nurses in Hong Kong: Implications for human resource practices and interventions. Asia Pacific Journal of Human Resources, 45(1), 63-84. doi: https://doi.org/10.1177/1038411107073604

Lian, H., Ferris, D. L., \& Brown, D. J. (2012). Does power distance exacerbate or mitigate the effects of abusive supervision? It depends on the outcome. Journal of Applied Psychology, 97(1), 107-123. doi: https://doi.org/10.1037/a0024610

Mackey, J. D., Frieder, R. E., Brees, J. R., \& Martinko, M. J. (2017). Abusive supervision: A meta-analysis and empirical review. Journal of Management, 43(6), 1940-1965. doi: https://doi.org/10.1177/0149206315573997

Marcus, B., \& Schuler, H. (2004). Antecedents of counterproductive behavior at work: A general perspective. Journal of Applied Psychology, 89(4), 647-660. doi: https://doi.org/10.1037/0021-9010.89.4.647

Martinko, M. J., Harvey, P., Brees, J. R., \& Mackey, J. (2013). A review of abusive supervision research. Journal of Organizational Behavior, 34(S1), 120-137. doi: https://doi.org/10.1002/job.1888

Maslach, C., \& Jackson, S. E. (1979). Burned-out cops and their families. Psychology Today, 12(12), 59-62. doi: https://doi.org/10.1007/BF01121154.

Mitchell, M. S., \& Ambrose, M. L. (2007). Abusive supervision and workplace deviance and the moderating effects of negative reciprocity beliefs. Journal of Applied Psychology, 92(4), 1159-1168. doi: https://doi.org/10.1037/0021-9010.92.4.1159

Nathanson, C., Paulhus, D. L., \& Williams, K. M. (2006). Personality and misconduct correlates of body modification and other cultural deviance markers. Journal of Research in Personality, 40(5), 779-802. doi: https://doi.org/10.1016/j.jrp.2005.09.002

Padilla, A., Hogan, R., \& Kaiser, R. B. (2007). The toxic triangle: Destructive leaders, susceptible followers, and conducive environments. The Leadership Quarterly, 18(3), 176-194. doi: https://doi.org/10.1016/j.leaqua.2007.03.001

Paulhus, D. L., \& Williams, K. M. (2002). The dark triad of personality: Narcissism, machiavellianism, and psychopathy. Journal of Research in Personality, 36(6), 556-563. doi: https://doi.org/10.1016/S0092-6566(02)00505-6 
Penney, L. M., \& Spector, P. E. (2002). Narcissism and counterproductive work behavior: Do bigger egos mean bigger problems?. International Journal of Selection and Assessment, 10(1-2), 126-134. doi: https://doi.org/10.1111/1468-2389.00199

Priesemuth, M., Schminke, M., Ambrose, M. L., \& Folger, R. (2014). Abusive supervision climate: A multiple-mediation model of its impact on group outcomes. Academy of Management Journal, 57(5), 1513-1534.

doi: https://doi.org/10.5465/amj.2011.0237

Qayyum, W., \& Siddiqui, R. (2007). Causes of youth unemployment in Pakistan [with comments]. The Pakistan Development Review, 46(4), 611-621.

Raskin, R. N., \& Hall, C. S. (1979). A narcissistic personality inventory. Psychological Reports, 45, 590. doi: https://doi.org/10.2466/pr0.1979.45.2.590

Savicki, V., \& Cooley, E. (1983). Theoretical and research considerations of burnout. Children and Youth Services Review, 5(3), 227-238.

doi: https://doi.org/10.1016/0190-7409(83)90028-2

Shepherd, D. A., Patzelt, H., \& Wolfe, M. (2011). Moving forward from project failure: Negative emotions, affective commitment, and learning from the experience. Academy of Management Journal, 54(6), 1229-1259. doi: https://doi.org/10.5465/amj.2010.0102

Shoss, M. K., Eisenberger, R., Restubog, S. L. D., \& Zagenczyk, T. J. (2013). Blaming the organization for abusive supervision: The roles of perceived organizational support and supervisor's organizational embodiment. Journal of Applied Psychology, 98(1), 158-168. doi: https://doi.org/10.1037/a0030687

Spain, S. M., Harms, P., \& LeBreton, J. M. (2014). The dark side of personality at work. Journal of Organizational Behavior, 35(S1), S41-S60.

doi: https://doi.org/10.1002/job.1894

Suchowlansky, M. (2017). Machiavelli's legacy: The Prince after 500 years. Contemporary Political Theory, 16(2), 286-289. doi: https://doi.org/10.1057/cpt.2016.17

Taufail, M., Hussain, S., \& Shahzad, K. (2018). Combined effects of job insecurity and Islamic work ethics on job satisfaction and job performance. Journal of Business $\mathcal{E}$ Economics, 10(2), 1-24.

Tepper, B. J. (2000). Consequences of abusive supervision. Academy of Management Journal, 43(2), 178-190. doi: https://doi.org/10.5465/1556375

Tepper, B. J., Duffy, M. K., Henle, C. A., \& Lambert, L. S. (2006). Procedural injustice, victim precipitation, and abusive supervision. Personnel Psychology, 59(1), 101-123. doi: https://doi.org/10.1111/j.1744-6570.2006.00725.x

Tepper, B. J., Moss, S. E., \& Duffy, M. K. (2011). Predictors of abusive supervision: Supervisor perceptions of deep-level dissimilarity, relationship conflict, and subordinate performance. Academy of Management Journal, 54(2), 279-294.

doi: https://doi.org/10.5465/AMJ.2011.60263085

Tepper, B. J., Simon, L., \& Park, H. M. (2017). Abusive supervision. Annual Review of Organizational Psychology and Organizational Behavior, 4, 123-152.

doi: https://doi.org/10.1146/annurev-orgpsych-041015-062539 
Wang, R., \& Jiang, J. (2014). How narcissistic employees respond to abusive supervision: Two roles of narcissism in decreasing perception and increasing deviance. Psychological Reports, 115(2), 372-380. doi: https://doi.org/10.2466/01.21.PR0.115c22z2

Westen, D. (1990). The relations among narcissism, egocentrism, self-concept, and selfesteem: Experimental, clinical, and theoretical considerations. Psychoanalysis and Contemporary Thought, 13(2), 183-239.

Zhang, Y., \& Bednall, T. C. (2016). Antecedents of abusive supervision: A meta-analytic review. Journal of Business Ethics, 139(3), 455-471. doi: https://doi.org/10.1007/s10551015-2657-6

Zhang, Y., \& Liao, Z. (2015). Consequences of abusive supervision: A meta-analytic review. Asia Pacific Journal of Management, 32(4), 959-987. doi: https://doi.org/10.1007/s10490-015-9425-0 